\title{
Complementary effects of cell wall degrading enzymes together with lactic acid fermentation on cassava tuber cell wall breakdown
}

Adeoluwa I. Adetunji ${ }^{\mathrm{a}}$, Heidi du Clou ${ }^{\mathrm{b}}$, Stephen N. Walford ${ }^{\mathrm{b}}$ and John R.N. Taylor ${ }^{\mathrm{a}, \mathrm{c}}$

${ }^{\mathrm{a}}$ Institute for Food, Nutrition and Well-being and Department of Food Science, University of Pretoria, Private Bag X20, Hatfield 0028, South Africa

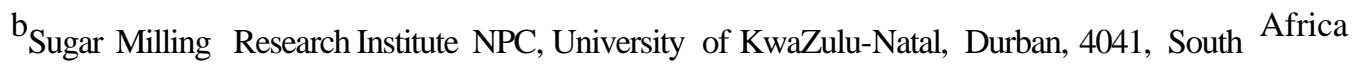

${ }^{\mathrm{C}}$ Corresponding author: Prof J.R.N. Taylor, Institute for Food, Nutrition and Well-being and Department of Food Science, University of Pretoria, Private Bag X20, Hatfield 0028, South Africa. E-mail: John.taylor@up.ac.za. Tel: +27 124204296. Fax: +27 124202839.

\section{Highlights}

- Combining cell wall degrading enzymes with fermentation enabled starch release.

- Lowering of $\mathrm{pH}$ by fermentation optimizes enzyme activity.

- Lignified cell wall materials were resistant to the cell wall degrading enzymes.

- Gum and hemicellulose hydrolysis exposes cellulosic material to breakdown. 


\begin{abstract}
Entrapment of starch granules within cassava parenchyma cells constitutes a major challenge in starch extraction from cassava tuber. This was addressed by applying cellulolytic and hemicellulolytic enzymes coupled with spontaneous lactic acid bacteria fermentation in the pretreatment of wet milled cassava. The hydrolytic activities of the enzymes and $\mathrm{pH}$ lowering by the fermentation resulted in fragmentation of the cassava cell walls, with improved release of free starch granules. The residual cell wall material after the treatments was characterized by microscopy and gas chromatography. Lignified material was resistant to hydrolysis. Material that was not hydrolysed by the enzymes consisted of arabinose, galactose, rhamnose, xylose and glucose, with the latter two the most abundant. It appears that the gums and hemicelluloses were hydrolysed first, enabling subsequent hydrolysis of the cellulosic materials. The complementary effects of these treatments could improve wet milling extraction of cassava starch.
\end{abstract}

Keywords: Cassava tuber; cellulolytic; hemicellulolytic; lactic acid fermentation; parenchyma cell walls; starch

Abbreviations: CWM, cell wall material; LAB, Lactic Acid Bacteria; TA, Titratable Acidity 


\section{Introduction}

Cassava (Manihot esculenta Crantz L.) is grown mainly for its large starch-rich storage roots (Blagbrough et al., 2010). Cassava serves as an important food crop for millions of people in tropical and sub-tropical Africa, Asia and Latin America. After rice and maize, cassava is the third most important source of calories in the world (FAO, 2015). The agronomic characteristics of the cassava crop such as its tolerance to low-fertility soil and drought stress contribute to its global economic importance (Poonsrisawat et al., 2014). Total cassava world production in 2013 was approx. 277 million tonnes, of which Africa represented about 57\% (FAO, 2015).

Proximate analysis of five different cassava genotypes indicated that starch and crude fibre composition ranges between $80-86 \%$ and $1.5-3.5 \%$ dry weight basis, respectively (Charles et al., 2005). Ccassava root tuber is processed commercially mostly for its starch (Teixeira et al., 2009). The process of extracting cassava starch is mostly by wet milling, due to the root's high moisture content (between 60-70\%) (reviewed by Breuninger et al., 2009). In the cassava tuber, the starch granules are located within the parenchyma cells (Sriroth et al., 2000b). The process of extracting the starch involves pre-cutting the tuber into small pieces before rasping to open up the cells to release the starch granules. However, the efficiency of cassava starch extraction and yield are low due to a substantial quantity of starch not being recovered from the pulp (cell wall materials) (Dzogbefia et al., 2008). This is attributable to the starch granules being trapped within the parenchyma cells. In fact, the residual starch content of the pulp can range between 50 and 60\%, dry weight basis (Sriroth et al., 2000a). 
Improvement in starch extraction and starch yield through the use of hydrolytic enzymes have been investigated to treat the cassava mash and the waste materials (Sriroth et al., 2000a;

Dzogbefia et al., 2008; Teixeira et al., 2009). Enzymatic hydrolysis opens up the compact cell wall structure leading to the release of the trapped starch granules (Kordylas, 1990). However, the right combination of suitable enzymes has been noted to be fundamental in the pretreatment of the cassava mash in order to achieve an increase in starch extraction (Dzogbefia et al., 2008). Traditionally, cassava root tubers are commonly processed by spontaneous lactic acid bacteria (LAB) fermentation in producing food products such as gari (fried cassava flakes) (Kostinek et al, 2005). As reported by Kostinek et al. (2007), a wide range of endogenous LAB have been characterized in cassava root tuber.

Hence, application of suitable exogenous enzyme treatments with multiple cell wall degrading activities to the cassava cake (wet milled cassava tuber) coupled with LAB fermentation could more effectively modify the cassava cell wall structure. The objective of this study was to examine treatment of cassava tuber after wet milling using cellulolytic and hemicellulolytic enzymes in combination with LAB fermentation.

\section{Materials and Methods}

\subsection{Mate rials}

Fresh cassava root tubers grown in Mozambique were obtained from a retail outlet in Pretoria. The commercial enzyme preparations used were Viscozyme L (a cocktail of cellulase and multihemicellulase enzymes) and Ultraflo Max (a cocktail of multi-hemicellulase enzymes), and Termamyl SC (a thermal-stable $\alpha$-amylase enzyme) kindly provided by Novozymes (Benmore, 
South Africa). The Ultraflo preparation has $\beta$-glucanase, xylanase and other pentosanase activities, while the Viscozyme enzyme preparation has $\beta$-glucanase, cellulase, xylanase, pentosanase (presumably more general pentosanase) and arabanase activities (Novozymes, 2008).

\subsection{Methods}

Pre-weighed fresh cassava root tubers were washed, peeled, chopped into chips and re-weighed. The cassava chips were milled using a Waring blender for $2 \mathrm{~min}$ at low speed and $1 \mathrm{~min}$ at high speed, with a small quantity of water added to aid the wet milling process. After milling, the cassava cake (wet milled cassava tuber) was weighed again.

\subsubsection{Effects of the enzyme preparations on cas sava cell wall degradation}

Cassava cake (450 g) was weighed into beakers. Nine ml Viscozyme and Ultraflo enzyme solution, individually and in 50:50 combination, were diluted with distilled water and added to give $250 \mathrm{ppm}$ of the enzyme preparations (relative to cassava cake solids) and mixed thoroughly. The cassava cake samples were covered with Parafilm to obtain an anaerobic condition to aid spontaneous LAB fermentation. A control treatment was obtained by mixing the cassava cake with $9 \mathrm{ml}$ distilled water. The cassava cake samples were incubated at $24^{\circ} \mathrm{C}$ for one week and two weeks. The treatments were performed twice. Enzyme activity was stopped by freezing the cassava cake samples at $-20^{\circ} \mathrm{C}$.

Spontaneous fermentation of the cassava cake by LAB was monitored over the period of incubation by determining the $\mathrm{pH}$ and titratable acidity (TA). TA was expressed as $\%$ lactic acid equivalents. 


\subsubsection{Starch removal}

Starch was removed to enable characterization of the remaining cassava cell wall materials after incubation. It was carried out using a BRF mashing bath (Brewing Research Foundation, Nutfield, UK). The pH of the cassava cake samples was adjusted to pH 5.0 with $0.1 \mathrm{M} \mathrm{NaOH}$ solution, the optimum $\mathrm{pH}$ for the $\alpha$-amylase used. Six ml diluted Termamyl SC was added to give $100 \mathrm{ppm}$ of the enzyme preparation in the slurry. It was then cooked for $1 \mathrm{hr}$ at $96^{\circ} \mathrm{C}$. After cooking for $1 \mathrm{hr}, 1 \mathrm{ml}$ full strength Termamyl SC was added to the mash and the cooking continued until the starch was negative by iodine. After starch removal, the samples were centrifuged at $470 \mathrm{~g}$ for $2 \mathrm{~min}$ and the clear supernatant carefully removed. The insoluble solids residue was frozen for later analysis.

\subsubsection{Purification of the treated cas sava cake and mashed solid materials}

After incubation for one week and two weeks, $25 \mathrm{~g}$ cassava cake samples before and after were weighed and diluted to $50 \mathrm{~g}$ with distilled water in $100 \mathrm{ml}$ glass centrifuge tubes. They were centrifuged at $470 \mathrm{~g}$ for $2 \mathrm{~min}$ and the clear supernatant carefully removed. The samples were then re-suspended in distilled water and re-centrifuged in order to completely wash out the soluble solids and this was repeated four times in total. The purified residual solid materials of the treated cassava cake samples both before and after starch removal were analysed for total solids, starch, soluble and insoluble fibre contents, particle size (sieve analysis) and by light microscopy. 


\subsection{Analys es}

\subsubsection{Total solids}

Total solids content of the washed enzyme treated and untreated cassava cake samples was determined based on dry matter remaining, by drying at $103^{\circ} \mathrm{C}$ for $3 \mathrm{hr}$.

\subsubsection{Starch content}

Starch content of the cellulolytic and hemicellulolytic enzyme treated and untreated cassava cake samples before starch removal was determined using the Megazyme Total Starch Assay Procedure (Amyloglucosidase/ $\alpha$-Amylase Method) (Megazyme International, 2011).

\subsubsection{Insoluble fibre content}

After starch removal and washing of the remaining solid material to remove the soluble solids, total insoluble fibre content was estimated based on the dry matter remaining, by drying at $103^{\circ} \mathrm{C}$ for $3 \mathrm{hr}$.

\subsubsection{Particle size}

Particle size of the cassava cake samples before and after starch removal was determined by weighing $10 \mathrm{~g}$ samples of the cassava cake samples and then sieving through 500 and $250 \mu \mathrm{m}$ opening sieves with small amount of distilled water. The solid materials retained by the 500 and $250 \mu \mathrm{m}$ sieves and the materials that passed through the $250 \mu \mathrm{m}$ sieve were dried and then weighed. 


\subsubsection{Light microscopy}

Microscopic examination of the cassava cake samples was carried out before and after starch removal, as well as on the particle size fractions. The cake samples before starch removal were stained with iodine solution to identify the starch granules.

\subsubsection{Gas chromatography characte rization of hydrolyzable residual cell wall materials}

Purified remaining insoluble cell wall materials were freeze dried. They were characterized for compositional and structural properties, as described by Ciucanu and Caprita (2007) and Laine et al. (2002), respectively, but with modifications as outlined in du Clou and Walford (2010). Hydrolysis of the cell wall materials into their monosaccharide components was carried out with acidified methanol. Samples for structural analysis were first per-methylated using Hakamori’s reagent in dimethyl sulphoxide (Hakamori 1965). This was followed by hydrolysis with acidified methanol. Following derivatization, the cell wall monosaccharide structural linkages were determined using a GC fitted with a VF-5ms column (Agilent Technologies, Santa Clara, CA) and flame ionization detector. For composition analysis, $1 \mu \mathrm{L}$ of sample was injected at a 1:100 split with the injector temperature set at $280^{\circ} \mathrm{C}$. The carrier gas was nitrogen, set at a flow of 1.3 $\mathrm{mL} / \mathrm{min}$. The initial oven temperature of $140^{\circ} \mathrm{C}$ was held for $1 \mathrm{~min}$ before rising to $158^{\circ} \mathrm{C}$ (at $2^{\circ} \mathrm{C} / \mathrm{min}$ ), then $186^{\circ} \mathrm{C}$ (at $1^{\circ} \mathrm{C} / \mathrm{min}$ ), then $280^{\circ} \mathrm{C}$ (at $10^{\circ} \mathrm{C} / \mathrm{min}$ ) and holding for $2 \mathrm{~min}$. For structural linkage analysis, the injector temperature was set at $260^{\circ} \mathrm{C}$ and the gas flow rate at 1 $\mathrm{mL} / \mathrm{min}$. The oven programme was altered so that the initial temperature was $100^{\circ} \mathrm{C}$, holding for $2 \mathrm{~min}$, before rising to $180^{\circ} \mathrm{C}$ (at $2^{\circ} \mathrm{C} / \mathrm{min}$ ), then $300^{\circ} \mathrm{C}$ (at $40^{\circ} \mathrm{C} / \mathrm{min}$ ) and holding for $2 \mathrm{~min}$. 


\subsection{Statistical analysis}

All experiments were repeated at least once. The independent variables were treatment of the cassava cake with enzyme and incubation period, while the dependent variables were the total solids, starch and insoluble fibre contents determined. Data were analysed by one-way analysis of variance. Significant differences among the means were determined by Fisher’s least significant difference test at $\mathrm{p}<0.05$.

\section{Results and Discussion}

The moisture content of the cassava root tuber was approx. 58\% (Table 1). The starch content of the total solids was approx. 85\% (dry weight basis). Hence, the starch content of the cassava cake was approx. 36\% (fresh basis), similar to the 34.7\% reported by Charles et al. (2004). The remaining $15 \%$ of the total solids consisted mainly of non-starch polysaccharides (both soluble and insoluble cell wall materials); as there are only trace levels of protein, lipids and ash in cassava tuber (Blagbrough et al., 2010).

\subsection{Effects of cell wall degrading enzyme preparations on cassava cake composition}

The $\mathrm{pH}$ of the cassava cake at day 0 was $\mathrm{pH} 6.4$ and after $24 \mathrm{hr}$ it had dropped to $\mathrm{pH} 4.3$. This large change in $\mathrm{pH}$ was due to the activity of LAB, such Lactobacillus plantarum which has been isolated from cassava roots (Giraud et al., 1991) and was found to be present in these particular cassava fermentations by MALDI-TOF analysis (unpublished data). After $24 \mathrm{hr}$, the rate of drop in $\mathrm{pH}$ of the cake slowed considerably. The $\mathrm{pH}$ after incubation for two weeks with the Viscozyme enzyme treatment was $\mathrm{pH} 3.7$ (Table 1). The $\mathrm{pH}$ after incubation for two weeks for both Ultraflo and combined enzymes treatments was $\mathrm{pH}$ 3.8, while that of untreated control 
Table 1: Effects of combining Viscozyme and Ultraflo on the insoluble solids content of cassava cake, cake total starch content and particle size distribution

\begin{tabular}{|c|c|c|c|c|c|c|c|c|}
\hline \multirow[t]{2}{*}{ Treatments } & \multirow[t]{2}{*}{ pH } & \multirow{2}{*}{$\begin{array}{c}\text { Titratable } \\
\text { acidity } \\
\text { (\% lactic acid } \\
\text { equivalent) }\end{array}$} & \multirow{2}{*}{$\begin{array}{l}\text { Insoluble solids } \\
\text { content } \\
\left.\text { (g/100 g cake }{ }^{2}\right)\end{array}$} & \multirow{2}{*}{$\begin{array}{c}\text { Starch content } \\
\text { (g/100 } \text { g insoluble } \\
\left.\text { solids }^{3}\right)\end{array}$} & \multirow[t]{2}{*}{$\begin{array}{l}\text { Starch content } \\
\left(\mathrm{g} / 100 \mathrm{~g} \mathrm{cake}^{2}\right)\end{array}$} & \multicolumn{3}{|c|}{$\begin{array}{l}\text { Sieved particle size fraction } \\
\qquad(\%)\end{array}$} \\
\hline & & & & & & $\begin{array}{l}\geq 500 \\
(\mu \mathrm{m})\end{array}$ & $\begin{array}{c}>250-<500 \\
(\mu \mathrm{m})\end{array}$ & $\begin{array}{l}\leq 250 \\
(\mu \mathrm{m})\end{array}$ \\
\hline Cass ava cake $^{1}$ & $6.39 \pm 0.01$ & ND & $42.5 \pm 0.1$ & $84.6 \pm 0.8$ & $36.0 \pm 0.2$ & ND & ND & ND \\
\hline *Control (1 week) & $4.09 \pm 0.01$ & $0.21 \pm 0.01$ & 46.6 & 82.4 & 38.4 & $54.9^{c} \pm 0.5$ & $2.5^{\mathrm{a}} \pm 0.1$ & $42.6^{\mathrm{a}} \pm 0.7$ \\
\hline Control (2 weeks) & $4.10 \pm 0.10$ & $0.17 \pm 0.06$ & $42.6^{\mathrm{b}} \pm 0.9$ & $87.0^{\mathrm{b}} \pm 0.3$ & $37.1^{\mathrm{cd}} \pm 0.9$ & $54.4^{\complement} \pm 2.8$ & $3.5^{\mathrm{ab}} \pm 0.5$ & $42.0^{\mathrm{a}} \pm 2.5$ \\
\hline Ultraflo (1 week) & $3.96 \pm 0.06$ & $0.26 \pm 0.01$ & $43.8^{\mathrm{b}} \pm 1.5$ & $86.0^{b} \pm 0.8$ & $37.7^{\mathrm{d}} \pm 1.6$ & $17.6^{b} \pm 2.5$ & $12.2^{\mathrm{a}} \pm 4.0$ & $70.3^{0} \pm 1.5$ \\
\hline Ultraflo (2 weeks) & $3.80 \pm 0.01$ & $0.29 \pm 0.02$ & $39.1^{\mathrm{a}} \pm 0.4$ & $85.8^{\mathrm{b}} \pm 1.0$ & $33.6^{\mathrm{b}} \pm 0.1$ & $12.6^{\mathrm{a}} \pm 1.7$ & $8.1^{\mathrm{bcd}} \pm 0.3$ & $79.4^{\mathrm{c}} \pm 2.0$ \\
\hline Viscozyme (1 week) & $3.96 \pm 0.05$ & $0.28 \pm 0$ & $43.4^{\mathrm{D}} \pm 0.2$ & $81.9^{\mathrm{a}} \pm 0.1$ & $35.5^{c} \pm 0.1$ & $12.5^{\mathrm{a}} \pm 1.6$ & $8.9^{\mathrm{ca}} \pm 2.5$ & $78.8^{\mathrm{c}} \pm 4.0$ \\
\hline Viscozyme (2 weeks) & $3.67 \pm 0.04$ & $0.40 \pm 0$ & $38.6^{\mathrm{a}} \pm 0.2$ & $82.4^{\mathrm{a}} \pm 0.9$ & $31.8^{\mathrm{a}} \pm 0.2$ & $10.1^{\mathrm{a}} \pm 0.6$ & $8.2^{\mathrm{bcd}} \pm 1.9$ & $81.8^{\mathrm{c}} \pm 1.3$ \\
\hline Visco+Ultra(1 week) & $3.94 \pm 0.08$ & $0.26 \pm 0.02$ & $38.4^{\mathrm{a}} \pm 0.5$ & $85.9^{\circ} \pm 0.2$ & $33.0^{\mathrm{ab}} \pm 0.5$ & $10.7^{\mathrm{a}} \pm 2.5$ & $6.3^{\mathrm{abc}} \pm 3.2$ & $83.2^{\mathrm{c}} \pm 5.7$ \\
\hline *Visco+Ultra(2 weeks) & $3.74 \pm 0.06$ & $0.29 \pm 0.03$ & $38.1^{\mathrm{a}} \pm 0.4$ & $82.8^{\mathrm{a}} \pm 0.4$ & $31.6^{\mathrm{a}} \pm 0.5$ & $9.0^{\mathrm{a}} \pm 0.5$ & $6.7^{\mathrm{abc}} \pm 0.4$ & $84.3^{\mathrm{c}} \pm 0.2$ \\
\hline
\end{tabular}

ND: Not determined;*Analysis not repeated; Mean values of two replicate treatments in the same column with different letters are significantly different (p<0.05); ${ }^{1}$ Cassava cake was not washed to remove soluble solids; ${ }^{2}$ As is basis; ${ }^{3}$ Dry weight basis. 


\section{a}

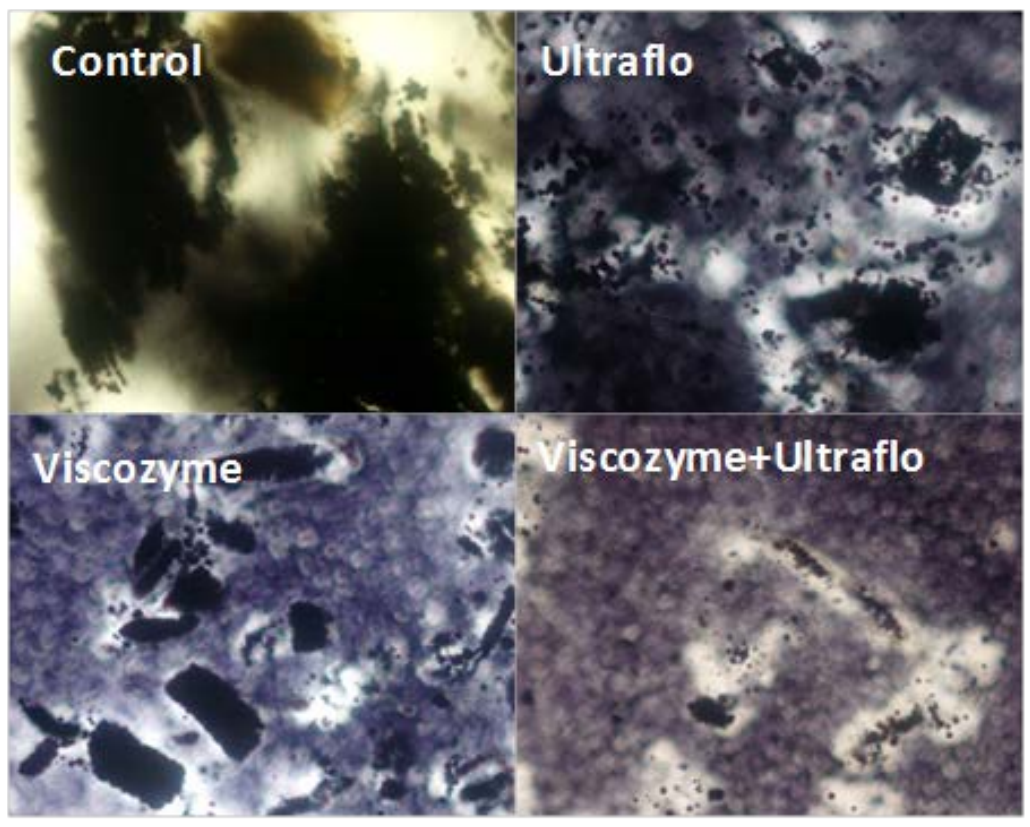

b

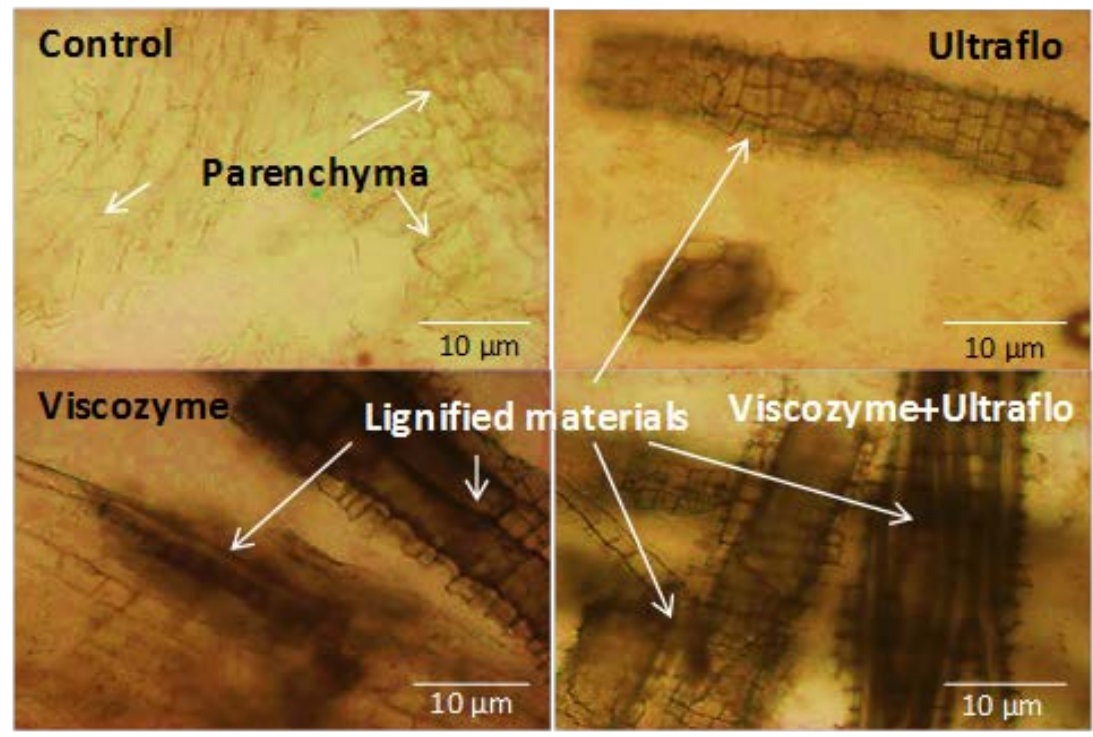

Figure 1: Light microscopy images of cassava insoluble solid residues showing the effects of Viscozyme and Ultraflo treatments on the cell wall materials incubated for two weeks; a. before starch removal; b. after starch removal. 
was $\mathrm{pH}$ 4.1. In agreement with the $\mathrm{pH}$, the Viscozyme treatment had higher TA than the Ultraflo and combined treatments. The untreated control had the lowest TA, which remained the same throughout the incubation period. The $\mathrm{LAB}$ fermentation provided the required $\mathrm{pH}$ range for the enzyme preparations to act. According to Novozymes (2008), effective performance of the enzyme preparations used are in the $\mathrm{pH}$ range of 3.5-5.8. The probable explanation for the greater drop in $\mathrm{pH}$ with the enzyme treated cakes was that the hydrolytic actions of the enzymes on the cell wall materials produced fermentable sugar substrates for the LAB.

The enzyme treated (Ultraflo, Viscozyme and combined treatment) cassava cake samples had lower insoluble solids than the untreated control (Table 1). The combined enzyme treatment and the Viscozyme treatment incubated for two weeks also resulted in a substantial reduction in the starch content of the cake, to approx. 32\% starch. This reduction in starch content suggests that the Viscozyme enzyme preparation had amylase side activity, thereby hydrolyzing the freed starch granules. Particle size distribution did not differ significantly between the enzyme treatments, but all the enzyme treatments yielded substantially $(\mathrm{p}<0.05)$ less large $(\geq 500 \mu \mathrm{m})$ and more small $(\leq 250 \mu \mathrm{m})$ particle size materials than the untreated control. Light microscopy of the cake insoluble solid materials after incubation for two weeks confirmed the reductions in size of the cell wall fibre materials in all the enzyme treatments coupled with increased amounts of freed starch granules, as indicated by the more diffuse background compared to the control treatment (Figure 1a).

The combined Ultraflo and Viscozyme treatment resulted in the greatest reduction in insoluble cell wall fibre materials in the cake (Table 2). This indicates that complementary hydrolytic activities were obtained by Viscozyme and Ultraflo coupled with LAB fermentation. Also, all the enzymatic treatments of the cassava cake resulted in a great reduction in the particle size of 
Table 2: Effects of combining Viscozyme and Ultraflo on non-starch solids and insoluble fibre contents and particle size of cassava cake

\begin{tabular}{|c|c|c|c|c|c|c|}
\hline \multirow[t]{2}{*}{ Treatments } & \multirow{2}{*}{$\begin{array}{c}\text { Non-starch } \\
\text { solids content } \\
\text { (g/100 g cake }{ }^{2} \text { ) }\end{array}$} & \multirow[t]{2}{*}{$\begin{array}{c}\text { Insoluble fibre } \\
\left(\% \text { solids }^{3}\right)\end{array}$} & \multirow[t]{2}{*}{$\begin{array}{l}\text { Insoluble fibre } \\
\text { (g/100 g cake) }\end{array}$} & \multicolumn{3}{|c|}{$\begin{array}{l}\text { Sieved particle size fraction } \\
\qquad(\%)\end{array}$} \\
\hline & & & & $\begin{array}{l}\geq \mathbf{5 0 0} \\
(\mu \mathrm{m})\end{array}$ & $\begin{array}{c}>250-<500 \\
(\mu \mathrm{m})\end{array}$ & $\begin{array}{l}\leq 250 \\
(\mu \mathrm{m})\end{array}$ \\
\hline${ }^{*}$ Control $(1 \text { week })^{1}$ & 8.2 & 5.7 & 2.6 & $92.1^{\mathrm{C}} \pm 0.1$ & $3.6^{\mathrm{ab}} \pm 1.3$ & $4.0^{\mathrm{a}} \pm 1.7$ \\
\hline Control (2 weeks) ${ }^{1}$ & $5.5^{\mathrm{ab}} \pm 0.0$ & $7.2^{\mathrm{d}} \pm 0.1$ & $3.0^{\mathrm{d}} \pm 0.1$ & $92.1^{\mathrm{c}} \pm 1.1$ & $2.4^{\mathrm{a}} \pm 0.7$ & $3.0^{\mathrm{a}} \pm 0.8$ \\
\hline Ultraflo $(1 \text { week })^{T}$ & $6.1^{\mathrm{bc}} \pm 0.1$ & $4.8^{\mathrm{C}} \pm 0.2$ & $2.1^{\mathrm{C}} \pm 0.0$ & $52.2^{\mathrm{b}} \pm 1.8$ & $7.8^{\mathrm{bc}} \pm 0.5$ & $39.9^{\mathrm{b}} \pm 2.7$ \\
\hline Ultraflo (2 weeks) ${ }^{1}$ & $5.6^{\mathrm{ab}} \pm 0.5$ & $3.6^{\mathrm{abc}} \pm 0.9$ & $1.4^{\mathrm{ab}} \pm 0.3$ & $44.9^{\mathrm{b}} \pm 2.2$ & $8.1^{\mathrm{bc}} \pm 1.6$ & $47.2^{\mathrm{b}} \pm 1.1$ \\
\hline Viscozyme (1 week) $^{1}$ & $7.9^{\mathrm{e}} \pm 0.1$ & $4.4^{\mathrm{bc}} \pm 1.0$ & $1.9^{\mathrm{bc}} \pm 0.4$ & $29.3^{\mathrm{a}} \pm 2.1$ & $12.5^{\mathrm{C}} \pm 4.8$ & $57.5^{\mathrm{c}} \pm 2.1$ \\
\hline Viscozyme (2 weeks) ${ }^{1}$ & $6.8^{\mathrm{d}} \pm 0.4$ & $3.4^{\mathrm{ab}} \pm 0.1$ & $1.3^{\mathrm{a}} \pm 0.0$ & $29.0^{\mathrm{a}} \pm 1.3$ & $9.4^{\mathrm{c}} \pm 0.3$ & $62.4^{\mathrm{C}} \pm 0.8$ \\
\hline Visco+Ultra $(1 \text { week })^{1}$ & $5.4^{\mathrm{a}} \pm 0.0$ & $3.0^{\mathrm{a}} \pm 0.0$ & $1.2^{\mathrm{a}} \pm 0.0$ & $33.8^{\mathrm{a}} \pm 0.3$ & $8.0^{\mathrm{bc}} \pm 0.3$ & $58.7^{\complement} \pm 0.4$ \\
\hline${ }^{*}$ Visco+Ultra $(2 \text { weeks })^{1}$ & $6.6^{\mathrm{cd}} \pm 0.1$ & $3.1^{\mathrm{a}} \pm 0.0$ & $1.2^{\mathrm{a}} \pm 0.0$ & 49.5 & 5.4 & 45.8 \\
\hline
\end{tabular}

*Analysis not repeated; Mean values of two replicate treatments in the same column with different letters are significantly different (p<0.05); ${ }^{1}$ Cassava slurry washed to remove soluble solids; ${ }^{2}$ As is basis; ${ }^{3}$ Dry weight basis 
the fibre materials compared to the untreated control. Light microscopy of the cake insoluble solids after removal of starch also revealed considerable differences in the cell wall material appearance (Figure 1b). With the combined enzyme treatment, the thin parenchyma cell walls had disappeared, and the remaining materials were thick, dark stained cell walls, indicating lignified material. The concentration of the lignified cell walls shows that these were not degraded by the enzyme preparations. This is because lignified materials contain few hydrolysable bonds and are poorly susceptible to hydrolytic enzymes (Marsden and Gray, 1986). The thin parenchyma cell walls are not lignified (McCluskey et al., 1984), which explains their complete degradation by the enzymes. In contrast, the untreated control still had clusters of intact thin parenchyma cell wall materials present (Figure 1b).

\subsection{Effects of the tre atment on cass ava cell wall structural composition}

As analysed by GC, the monosaccharide composition of the cassava residual CWM soluble in acidified methanol included arabinose, rhamnose, xylose, galactose and glucose (Table 3). Glucose was the major sugar unit of the CWM, and constituted about $85 \%$ of the remaining hydrolysable material in the control (untreated). Similar data were reported by Salvador et al. (2000) with the cellulose fraction of the cassava CWM having 82\% glucose. Xylose and galactose contents of the remaining CWM in the control (without enzymatic treatment) were 3 and $8 \%$, respectively. These levels were much lower than the $27 \%$ xylose and $38 \%$ galactose reported by Salvador et al. (2000). This could be due to enzymatic activity of the LAB in the cassava cake during incubation, which probably partially hydrolysed the soluble cell wall components. As characterized by Williams and Banks (1997), non-starter LABs have been found to exhibit a wide range of hydrolytic enzymic activities. 
Table 3: Sugar composition of cassava cell wall material (CWM) remaining after treatment with Ultraflo and Viscozyme

\begin{tabular}{|c|c|c|c|c|c|c|c|}
\hline Treatments & $\begin{array}{c}\text { Arabinose } \\
\text { (\%) }\end{array}$ & $\begin{array}{c}\text { Rhamnose } \\
(\%)\end{array}$ & $\begin{array}{c}\text { Xylose } \\
(\%)\end{array}$ & $\begin{array}{c}\text { Galactose } \\
\text { (\%) }\end{array}$ & $\begin{array}{c}\text { Glucose } \\
\text { (\%) }\end{array}$ & $\begin{array}{c}\text { Not } \\
\text { characterised } \\
(\%)\end{array}$ & $\begin{array}{c}\text { CWM not } \\
\text { hydrolysed } \\
\text { (\%) }\end{array}$ \\
\hline Control 1 week & $1.8(1.2)$ & $1.4(1.0)$ & $3.4(2.3)$ & $7.5(5.0)$ & $72.7(90.6)$ & 13.2 & 0 \\
\hline Control 2 weeks & $0.8(0.9)$ & $0.7(0.7)$ & $1.4(1.6)$ & $1.2(1.4)$ & $84.8(95.3)$ & 8.3 & 2.9 \\
\hline Ultraflo 1 week & $1.1(5.2)$ & $0.8(4.0)$ & $3.3(15.9)$ & $2.3(11.3)$ & $13.0(63.6)$ & 3.1 & 76.4 \\
\hline Ultraflo 2 weeks & $3.4(9.4)$ & $2.3(6.2)$ & 5.1(13.9) & $1.5(4.1)$ & $24.4(66.3)$ & 11.2 & 52.0 \\
\hline Viscozyme 1 week & $0.4(1.4)$ & $0.3(1.0)$ & $4.6(16.3)$ & $1.1(4.0)$ & $21.6(77.3)$ & 3.1 & 69.0 \\
\hline Viscozyme 2 weeks & $0.2(1.2)$ & $0.2(1.4)$ & $4.7(27.7)$ & $0.7(3.8)$ & $11.2(65.9)$ & 2.2 & 80.8 \\
\hline Visco/Ultra 1 week & $0.1(1.1)$ & $0.1(1.7)$ & $2.0(24.6)$ & $0.6(7.5)$ & $5.3(65.2)$ & 6.4 & 85.4 \\
\hline Visco/Ultra 2 weeks & $0.9(4.2)$ & $0.6(2.7)$ & $10.9(51.3)$ & $0.5(2.2)$ & 8.4(39.5) & 5.6 & 73.1 \\
\hline
\end{tabular}

Values in parentheses are relative percentages of sugar components in the remaining CWM after treatment with Ultraflo and Viscozyme. 
With the enzyme treated residual CWMs, there was a considerable reduction in the level of glucose compared to the control (Table 3). The combined Ultraflo and Viscozyme treatment had the lowest glucose content (5 and 8\%) in the residual CWMs incubated for one week and two weeks, respectively. In the separate enzyme treatments, the Viscozyme treated residual CWM had slightly lower content of glucose than the Ultraflo treated CWM. There was an increase in xylose content with a decrease in glucose content of the enzyme treated residual CWMs compared to the control. This indicates a higher level of degradation of cellulosic type components of the cassava cell walls by the Viscozyme enzyme preparation. This is presumably because the Viscozyme preparation has cellulase enzyme activity (Novozymes, 2008). The proportion of cell wall components not characterized generally decreased with the enzyme treatments. This component may have been lignified components hydrolysed by the acidified methanol. The proportion of residual CWM not hydrolyzed in acidified methanol increased with the enzyme treatments. The hhydrolysis of the non-starch polysaccharides components of the CWM by the enzyme activities resulted in concentration of the lignified materials, as shown in Fig 1b. As stated, lignified CWMs are more resistant to enzyme hydrolysis (Marsden and Gray, 1986).

Although the enzyme treated samples had a lower relative percentage of glucose compared to the control, the proportion was generally much higher in all the treatments than those of arabinose, rhamnose, and galactose. The combined Ultraflo and Viscozyme treatment, however, had the highest percentage of xylose after two weeks (Table 3). It appears that the combined enzyme preparation hydrolysed more of the cellulosic components of the CWM, resulting in a higher relative concentration of the hemicellulose component remaining. In the separate enzyme treatments, Viscozyme treated CWM had a much lower proportion of arabinose and a higher 
proportion of xylose, while Ultraflo treated CWM had a higher proportion of arabinose and a lower proportion of xylose. This indicates that Ultraflo had degraded more of the xylan, while Viscozyme had degraded more of the araban.

The glycosidic bonds considered for quantitation were those arising mainly from the remaining cellulosic component of the CWM i.e. 1,4-glycosidic, 1,6-glycosidic and terminal glycosidic bonds (Table 4). The proportion of these identified glycosidic bonds in the residual CWM after hydrolysis with Ultraflo and Viscozyme (separately and combination) was low ( $<50 \%)$ compared to the untreated control (>65\%) (Table 4). The linkages not characterized in the residual CWM were much higher in the enzyme treated samples than the untreated control. These uncharacterized linkages could include other glycosidic bonds (e.g. 1,3-glycosidic) and other non-glycosidic bonds. Non-glycosidic bonds are most likely due to the lignified components of the residual CWM that were hydrolyzed during the acidified methanol preparation of the CWM. This increase in uncharacterized linkages in the enzyme treated residual CWM analyzed, supports the concept of an increase in the relative concentration of lignified cell walls. In relation to the identified linkages, the relative percentage of 1,4-glycosidic linkages in all the treatments was much higher than terminal and 1,6-glycosidic bonds. The terminal glycosidic linkages in the enzyme treated residual CWMs decreased considerably compared to the untreated control residual CWM. This could be due to more complete hydrolysis of the cell wall matrix polymers holding together the cassava cell walls by the various hemicellulolytic enzyme activities. Combined activities of Ultraflo and Viscozyme preparations on the cell walls incubated for two weeks indicated that both terminal and 1,6-glycosidic bonds were completely hydrolysed, while the level of 1,4-glycosidic linkages obtained from the residual CWM were reduced considerably. In contrast, the proportion of 1,4-glycosidic linkages was much higher in the control CWM than 
Table 4: Different glycosidic linkages and their relative percentages in cassava cell wall material (CWM) remaining after treatment with Ultraflo and Viscozyme

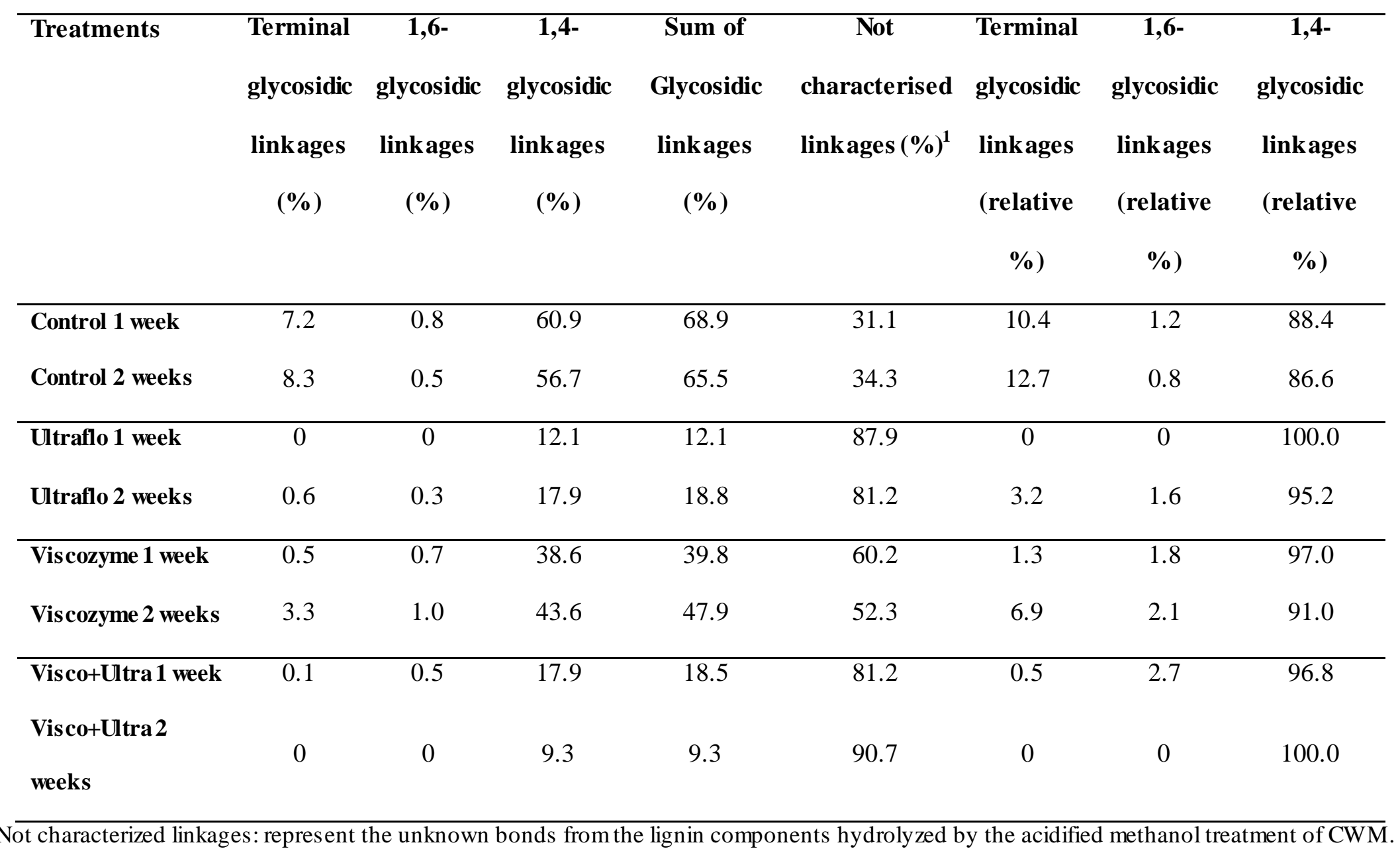


the enzyme treated samples. This high proportion of 1,4-glycosidic linkages in the control residual CWM can be linked with the parenchyma cell walls still intact, as shown in Figure 1. However, the relative percentage of 1,4-glycosidic linkages were higher in the enzyme treatments compared to the untreated control. This implies that there was more complete hydrolysis of the hemicellulosic cell wall polymers than the cellulosic cell wall polymers. These effects correspond with the various hemicellulolytic enzyme activities present in both enzyme preparations.

\subsection{Mechanism of cell wall breakdown in fre eing the trapped starch granules}

Based on the above findings, the proposed mode of hydrolysis of the cassava parenchyma cell wall polymer by the combined enzymatic treatment and activity of LAB to breakdown the cell wall and free the starch granules is illustrated in Figures 2 and 3. The fibrous nature of cassava storage roots develops through massive cell division and differentiation of parenchyma cells of the secondary xylem (Sheffield et al., 2006). The lignified cell wall materials in cassava root tuber are cross-linked phenylpropane units, which are made up of xylem tissue and schlerenchymous fibres (Buschmann et al,, 2002). As illustrated in Figure 2a, the general cell wall arrangement and structural organization is based on the primary cell walls referred to as cellulosic cell walls (Maieves et al., 2012). The secondary cell walls are made up of hemicellulosic polymers of arabinose, xylose, other pentoses with hexoses, glucuronic acids and some deoxyl sugars (Saha, 2003). The intracellular spaces contain pectic polysaccharides, which serve as adhesive connecting the cellulosic cell walls in the middle lamella (Maieves et al., 2012). In addition, cassava root tuber cell walls also contain soluble hemicellulose 

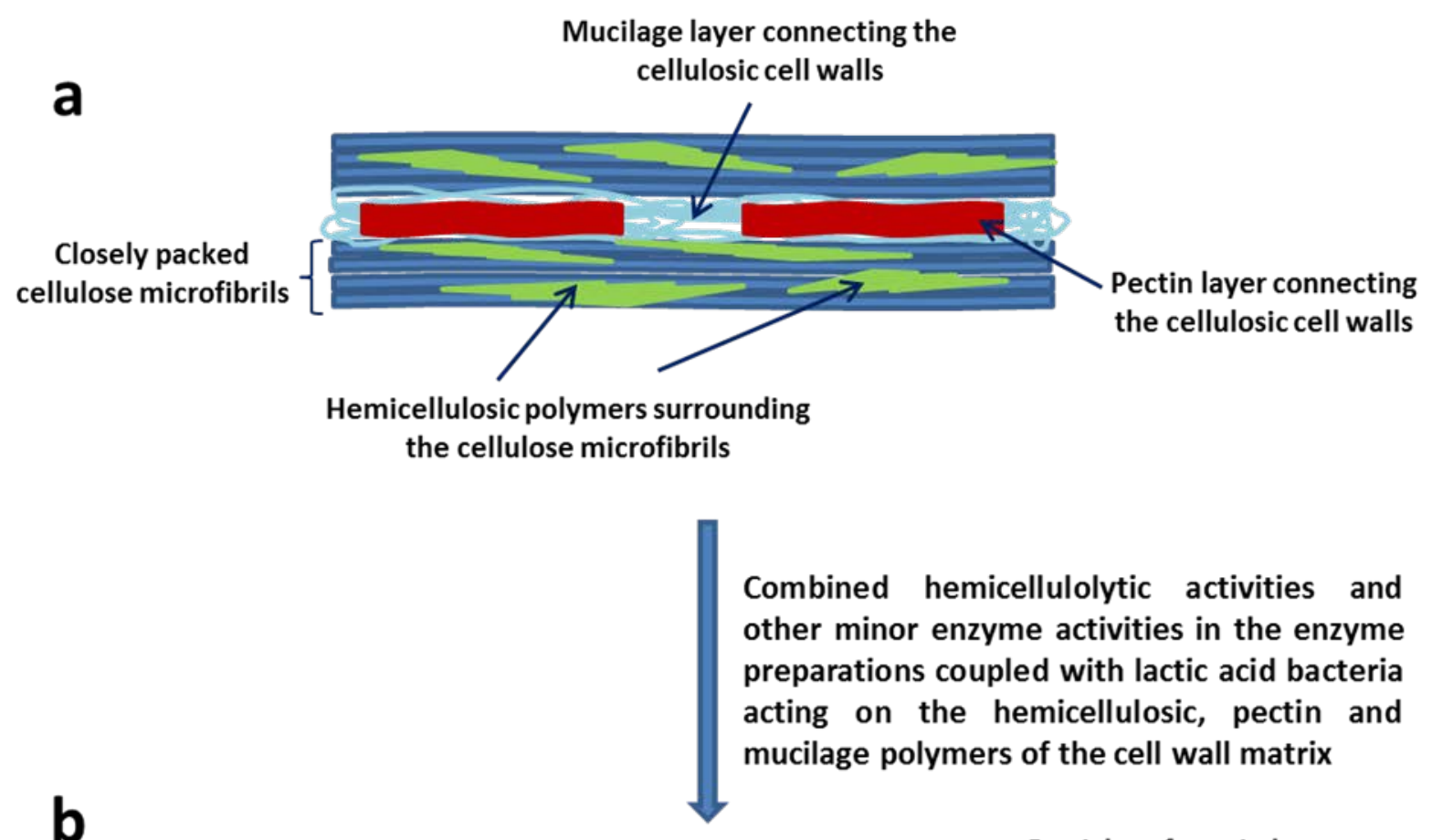

b

Particles of pectin layer

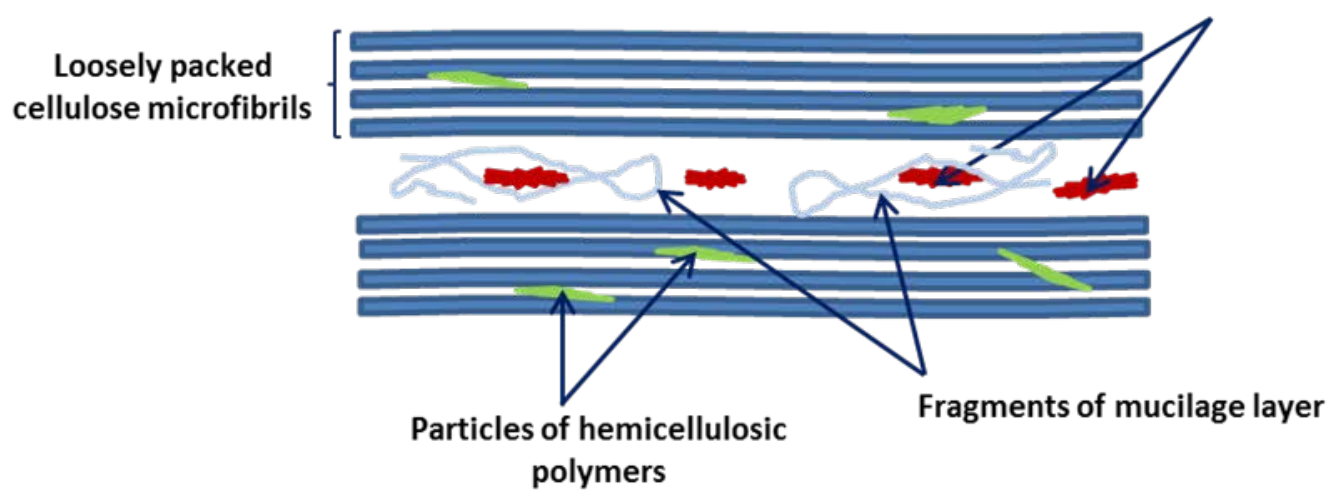

Figure 2: Schematic illustration of the proposed mechanism of the hemicellulolytic and other minor enzyme activities in the enzyme preparations coupled with lactic acid bacteria fermentation on the structure and composition of the cassava parenchyma cell walls.

a: Cell wall structural organization before the enzymatic treatment;

b: Hydrolysis of the mucilage, pectin and hemicellulosic polymers opening up the compact cellulosic cell walls. 


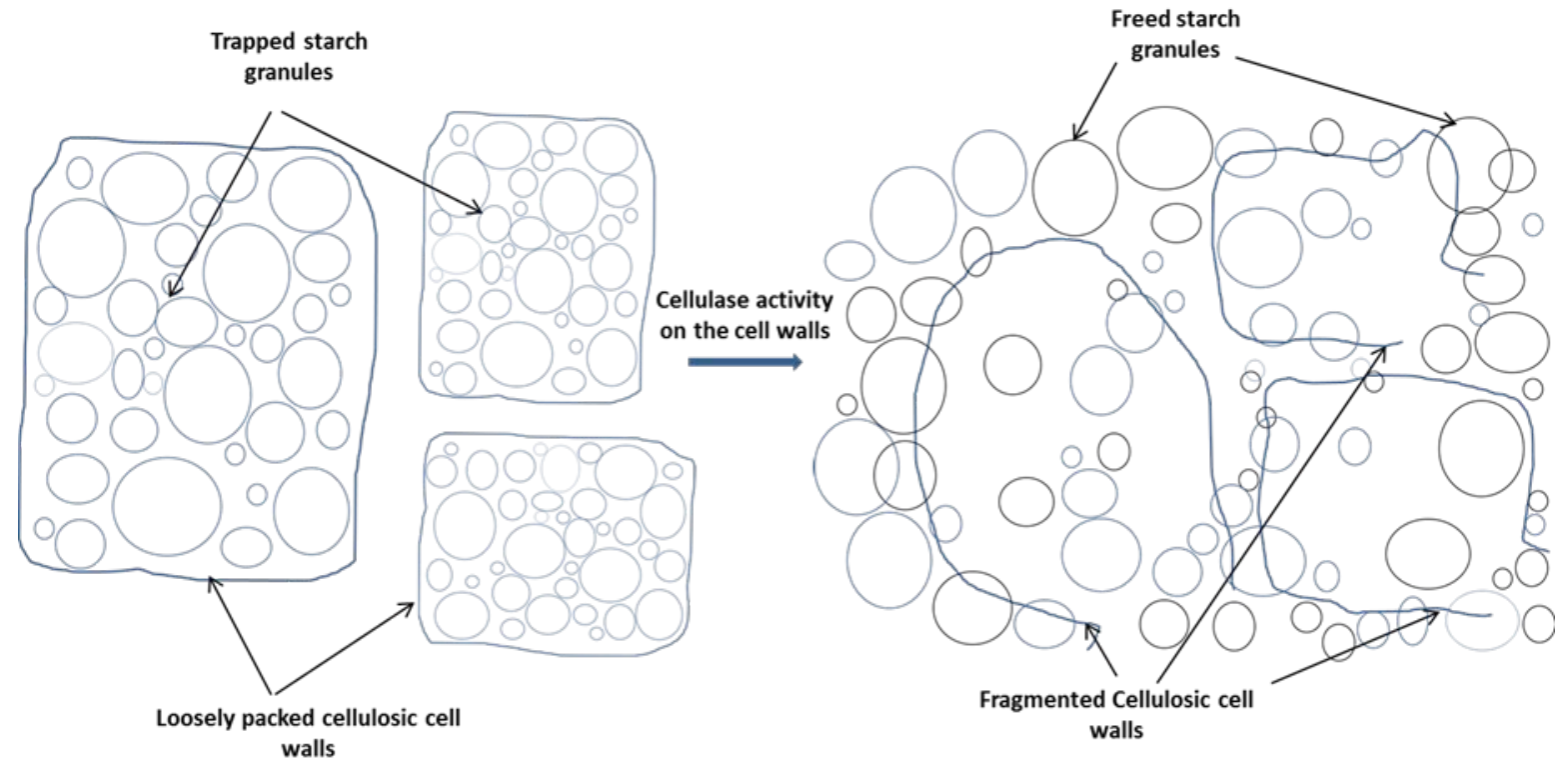

Figure 3: Schematic illustration of the effect of cellulase activity from the Viscozyme preparation on the loosely packed cellulose microfibrils, fragmenting the parenchyma cell walls and freeing the starch granules. 
mucopolysaccharides, known as cassava tuber mucilage (Charles et al., 2008). This mucilage also constitutes part of the adhesive components of the intercellular spaces.

Figure $2 \mathrm{~b}$ illustrates the hydrolytic actions of the various xylanases, pentosanases and arabanase in the enzyme preparations, as well as the activity of LAB on the soluble hemicellulos ic polymers around the closely packed cellulose microfibrils. Beta-glucanases coupled with minor enzyme activities in the enzyme preparations and LAB acted on the pectin polymers and mucilage in the intercellular spaces holding the cellulosic cell walls together. All these activities resulted in opening up of the compact structure of the cell walls through hydrolysis of the cell wall hemicellulosic polymers, pectin and mucillage layers, thereby exposing the cellulosic cell walls. With the cellulose microfibrils loosely packed (Figure 2b), this enabled access of the cellulase in the Viscozyme preparation to the cellulosic cell walls (Souza, et al., 1998). The cellulase activity resulted in fragmentation (breakdown) and hydrolysis of the cellulosic cell walls, hence releasing the trapped starch granules (Figure 3).

\section{Conclusions}

Combined activities of various hydrolytic enzymes in the Viscozyme and Ultraflo preparations, as well as the effect of LAB fermentation, results in fragmentation of the cassava tuber parenchyma cell walls. This facilitates improved release of starch granules trapped within the parenchyma cells. The mechanism of cassava tuber cell wall breakdown is based on the opening of the compact cell wall structure by the activities of hemicellulolytic enzymes, exposing the cellulosic parenchyma cell walls to the activity of cellulolytic enzymes. The complementary effects of combining this type of enzymatic treatment with LAB fermentation could effectively improve starch extraction process and yield in the production of starch from cassava root tubers 
after wet milling. In addition, this enzymatic pre-treatment technology should reduce the quantity of cassava bagasse residual CWM generated.

\section{Acknowledge ment}

SABMiller Africa for financial support.

\section{References}

Blagbrough, I.S., Bayoumi, S.A., Rowan, M.G., Beeching, J.R., 2010. Cassava: an appraisal of its phytochemistry and its biotechnological prospects. Phytochemistry 71, 1940-1951.

Breuninger, W. F., Piyachomkwan, K., Sriroth, K., 2009. Tapioca/cassava starch: production and use, in BeMiller, J.N.,Whistler, R.L. (Eds.), Starch: Chemistry and Technology. Elsevier, New York, pp. 541-568.

Buschmann, H., Potter, U., Beeching, J., 2002. Ultrastructure of cassava root studied by TEM and SEM. Microsc. Anal, 9-12.

Charles, A.L., Chang, Y.H., Ko, W.C., Sriroth, K., Huang, T.C., 2004. Some physical and chemical properties of starch isolates of cassava genotypes. Starch/Stärke 56, 413-418.

Charles, A.L., Sriroth, K., Huang, T., 2005. Proximate composition, mineral contents, hydrogen cyanide and phytic acid of 5 cassava genotypes. Food Chem. 92, 615-620.

Charles, A.L., Huang, T.C., Chang, Y.H., 2008. Structural analysis and characterization of a mucopolysaccharide isolated from roots of cassava (Manihot esculenta Crantz L.). Food Hydrocolloid. 22, 184-191. 
Ciucanu, I., Caprita, R., 2007. Per-O-methylation of neutral carbohydrates directly from aqueous samples for gas chromatography and mass spectrometry analysis. Anal. Chim. Acta 585, 81-85.

Du Clou, H., Walford S.N., 2010. An introduction to gas chromatography mass spectroscopy for the structural elucidation of polysaccharides from sugar processing streams. Proc. S. Afr. Sugar Technol. Assoc. 83, 392-409.

Dzogbefia, V.P., Ofosu, G.A., Oldham, J.H., 2008. Evaluation of locally produced Saccharomyces cerevisiae pectinase enzyme for industrial extraction of starch from cassava in Ghana. Sci. Res. Essay 3, 365-369.

Food and Agriculture Organization (FAO), 2015. FAOSTAT Agricultural database. http://www.faostat3.fao.org. Accessed: 9/03/2015.

Giraud, E., Brauman, A., Keleke, S., Lelong, B. and Raimbault, M., 1991. Isolation and physiological study of an amylolytic strain of Lactobacillus plantarum. Appl. Microbiol. Biot. 36, 379-383.

Hakamori, S.I., 1965. A rapid permethylation of glycolipid, and polysaccharide catalyzed by methylsulfinyl carbanion in dimethyl sulfoxide. J. Biochem. 55, 205-208.

Kordylas, J.M., 1990. Processing and Preservation of Tropical and Subtropical Foods, Macmillan Education, London, pp. 427.

Kostinek, M., Specht, I., Edward, V. A., Schillinger, U., Hertel, C., Holzapfel, W. H., Franz, C. M., 2005. Diversity and technological properties of predominant lactic acid bacteria from fermented cassava used for the preparation of Gari, a traditional African food. System. Appl. Microbiol. 28, 527-540. 
Kostinek, M., Specht, I., Edward, V. A., Pinto, C., Egounlety, M., Sossa, C., Mbugua, S., Dortu, C., Thonart, P., Taljaard, L., Mengu, M., Franz, C.M.A.P., Holzapfel, W. H., 2007.

Characterisation and biochemical properties of predominant lactic acid bacteria from fermenting cassava for selection as starter cultures. Int. J. Food Microbiol. 114, 342-351.

Laine, C., Tamminen, T., Vikkula, A., Vuorinen T., 2002. Methylation analysis as a tool for structural analysis of wood polysaccharides. Holzforschung 56, 607-614.

Maieves, H.A., De Oliveira, D.C., Bernardo, C., Muller, C.M.D., Amante, E.R. 2012.

Microscopy and texture of raw and cooked cassava (Manihot esculenta Crantz) roots. J. Text.

Stud. 4, 164-173.

Marsden, W.L., Gray, P.P., 1986. Enzymatic hydrolysis of cellulose in lignocellulosic materials. Crit. Rev. Biot. 3, 235-276.

McCluskey, J.G., Allison, M.J., Duncan, H.J., Jarvis, M.C., 1984. Isolation of anatomically defined cell walls from fodder kale, and their contributions to determining the in vitro cellulase digestibility of the whole plant. J. Agric. Sci. 103, 347-352.

Megazyme International, 2011. Colorimetric method for the determination of total starch and amylose contents. www.megazyme.com. Accessed: 23/04/2015.

Novozymes, 2008. Brewing Handbook, $4^{\text {th }}$ ed. Novozymes A/S, 243 Dittigen, Switzerland, pp. 71-82.

Poonsrisawat, A., Wanlapatit, S., Paemanee, A., Eurwilaichitr, L., Piyachomkwan, K., Champreda, V., 2014. Viscosity reduction of cassava for very high gravity ethanol fermentation using cell wall degrading enzymes from Aspergillus aculeatus. Process Biochem. 49, 1950-1957. 
Saha, B.C., 2003. Hemicellulose bioconversion. J. Ind. Microbiol. Biot. 30, 279-291.

Salvador, L.D., Suganuwa, T., Kitahara, K., Tanoue, H., Ichiki, M., 2000. Monosaccharide composition of sweetpotato fiber and cell wall polysaccharides from sweetpotato, cassava and potato analysed by the High-Performance Anion Exchange Chromatography with Pulsed Amperometric Detection Method. J. Agric. Food Chem. 48, 3448-3454.

Sheffield, J., Taylor, N., Fauquet, C. and Chen, S., 2006. The cassava (Manihot esculenta Crantz L.) root proteome: Protein identification and differential expression. Proteomics 6, 1588-1598.

Souza, P.A., Gomes-Filho, E., Campos, F.A., 1998. Tissue distribution and deposition pattern of a cellulosic parenchyma-specific protein from cassava roots. Braz. Arch. Biol. Technol. 41, 1-9.

Sriroth, K., Chollakup, R., Chotineeranat, S., Piyachomkwan, K., Oates, C.G., 2000a. Processing of cassava waste for improved biomass utilization. Bioresource Technol. 71, 63-69.

Sriroth, K., Piyachomkwan, K., Wanlapatit, S., Oates, C.G., 2000b. Cassava starch technology: the Thai experience. Starch/Stärke 52, 439-449.

Teixeira, E.D.M., Pasquini, D., Curvelo, A.A., Corradini, E., Belgacem, M.N., Dufresne, A., 2009. Cassava bagasse cellulose nanofibrils reinforced thermoplastic cassava starch. Carbohyd. Polym. 78, 422-431.

Williams, A. G., Banks, J. M., 1997. Proteolytic and other hydrolytic enzyme activities in nonstarter lactic acid bacteria (NSLAB) isolated from Cheddar cheese manufactured in the United Kingdom. Int. Dairy J. 7, 763-774. 